Journal de la Société des américanistes

Journal de la Société

des américanistes

\title{
Witchcraft as metaculture in the Bolivian Chaco
}

\section{Kathleen Lowrey}

\section{OpenEdition}

\section{Journals}

Electronic version

URL: https://journals.openedition.org/jsa/8103

DOI: $10.4000 /$ jsa. 8103

ISSN: $1957-7842$

\section{Publisher}

Société des américanistes

\section{Printed version}

Date of publication: 2 December 2007

Number of pages: 121-152

ISSN: 0037-9174

\section{Electronic reference}

Kathleen Lowrey, "Witchcraft as metaculture in the Bolivian Chaco", Journal de la Société des américanistes [Online], 93-2 | 2007, Online since 10 December 2012, connection on 02 September 2022. URL: http://journals.openedition.org/jsa/8103 ; DOI: https://doi.org/10.4000/jsa.8103

All rights reserved 


\title{
WITCHCRAFT AS METACULTURE IN THE BOLIVIAN CHACO
}

\author{
Kathleen LOWREY *
}

This paper treats a multi-village assembly that was held to adjudicate an accusation of witchcraft in the Guarani-speaking indigenous community of Isoso, in the Bolivian Chaco, in 1999. The argument of the article is that the leadership of this community attempted an anthropological treatment of a problem of witchcraft by addressing it at a « meta-cultural » level having to do with community dynamics. However, the Isoseño leadership found - as have anthropologists - that shifting the frame of reference of a problem is not the same as resolving it, and that conflict can be as casily transmuted as can frames of analysis. The article concludes that a sophisticated, reflexive selfconsciousness about culture on the part of modern indigenous leaders may not allow them to transcend culture in their home communities, any more than the culture concept has allowed anthropologists to solve their most puzzling disciplinary problems. [Key words: witchcraft, metaculture, Guaraní, indigenous peoples, Chaco.]

La brujeria como meta-cultura en el Chaco boliviano. El artículo trata de una asamblea que tuvo lugar en el Isoso, una comunidad indigena guarani-hablante del Chaco boliviano, en 1999. Reuniendo a varias aldeas, la asamblea se llevó a cabo para resolver una acusación de brujería. Se argumenta que los líderes isoseños procuraron enfrentar este problema en un plano "meta-cultural», encarándolo como un conflicto que expresa o manifiesta en alguna forma dinámicas comunitarias conflictivas. Sin embargo, los líderes isoseños descubrieron - al igual que los antropólogos - que el mero hecho de cambiar el marco de referencia de un problema no implica resolverlo, y que los conflictos pueden transmutarse con igual facilidad que los marcos analíticos. Se concluye que la sofisticada y reflexiva auto-conciencia que poseen los líderes indigenas contemporáneos sobre la cultura no les permite necesariamente trascender las expectativas de su cultura de origen - de la misma manera que el concepto de « cultura » no permitió a los antropólogos resolver sus rompecabezas disciplinarios más tenaces. [Palabras claves: brujería, meta-cultura, guaraní, pueblos indigenas, Chaco.]

La sorcellerie en tant que méta-culture dans le Chaco bolivien. Le point de départ de cet article est une assemblée qui eut lieu en 1999 dans l'Isoso, une communauté indienne guaranophone du Chaco bolivien. L'assemblée, qui réunissait plusieurs villages, avait été convoquée pour résoudre un cas d'accusation de sorcellerie. On argumente que les dirigeants isoseño s'efforcèrent d'affronter le problème à un niveau " méta-culturel ",

* Department of Anthropology, University of Alberta, 13-5 Tory Building, Edmonton, Canada T6G2H4 [klowrey@ualberta.ca].

Journal de la Société des Américanistes, 2007, 93-2, pp. 121-152. O Société des Américanistes. 
en le considérant comme un conflit exprimant ou manifestant d'une certaine façon des dynamiques communautaires conflictuelles. Les dirigeants isoseno ont cependant découvert - comme l'ont fait les anthropologues - que le seul fait de changer le cadre de référence d'un problème n'équivaut pas à le résoudre, et que les conflits peuvent se transmuter avec la même facilité que les cadres d'analyse. On conclut que la conscience sophistiquée et réflexive qui est celle des dirigeants indiens contemporains sur la culture ne leur permet pas toujours de transcender les attentes de leur culture d'origine - de la même façon que le concept de "culture " n'a pas permis aux anthropologues de résoudre leurs problèmes disciplinaires les plus complexes. [Mots-clés: sorcellerie, méta-culture, Guarani, peuples indigènes, Chaco.]

"Presumably, the mere reflection of a social predicament on to another plane is a way of coping with it. » (Shapin 1979, p. 49)

This article treats a multi-village ñemboati (Guaraní for «meeting » or " assembly ») convened to resolve a case of witchcraft accusation. It took place in Isoso in February 1999, during the first year of my dissertation fieldwork. The conflict involved a young woman who showed signs of pregnancy for more than a year, but in which gestation did not progress. She had consulted various practitioners in Isoso and out of it about the problem. A young medical doctor, performing his post-graduate year of rural service at the mini-hospital in Isoso's main village, diagnosed the most probable cause as a uterine tumor that he was not equipped to treat. The girl and her family, however, eventually concluded her condition was caused by witchcraft and, specifically, that an older woman in her village was bewitching her.

As will be shown, the facts of the case were not considered closely at the nemboati. Neither witchcraft as an art or practice, nor the problem of its presence or absence in this situation, were taken up at any length. Instead, the Isoseño authorities leading the meeting treated witchcraft, the dispute, and its resolution through reiterated reference to community solidarity. Rather than unpacking the specifics of the case, they bundled these particulars and treated the entire matter only insofar as it concerned legitimate structures of authority in Isoso.

A straightforward critique (that Shapin's skeptical line, quoted above, encapsulates) has been made of anthropological approaches to witchcraft that attempt the very agenda the Capitanía del Alto y Bajo Isoso (CABI) deployed at the meeting. If people want to thrash out a conflict, why do they bother to translate it into the idiom of witchcraft? Mightn't it be more reasonable to suppose that witchcraft is its own problematic, with characteristics best considered according to the lights of their irreducible peculiarity? Indeed, nemboati attendees were manifestly unsatisfied by CABI's translation of the witchcraft dispute away from the nuts-and-bolts of bewitchment. Isoseño people appeared to be as exasperated by the " translational » approach to witchery as are academic anthropological 
critics of the same. In the case of Isoso, this was evidenced by a lack of full participation in the communicative give and take of the assembly proper and in its formal closing. No one had come to the ñemboat in order to hear a lecture on the importance of fealty and collective solidarity in an era of rumor, suspicion, and misleading information. But that is what their leaders made sure that they got.

At the time of the meeting, CABI was beginning to confront considerable community dissent. Several months afterward, this turmoil culminated in a bifurcating schism over leadership in Isoso (a conflict that has not been resolved as of the present writing, seven years on). Having had quite a long time to think about the events of that day, I want to suggest that CABI was not wrong in its analysis of the underlying springs of « dis-ease » in the community (and that, by extension, nor are anthropological analyses made in the same mode). The witchcraft case presented - or at least, CABI leaders treated it as presenting - a pretext for an enactment of community solidarity in a milieu of rumors and both internal and external threat. In treating it in this fashion, however, CABI came up against the fact (confronted also by anthropologists) that re-interpreting a problem is not the same thing as resolving it. Although it is likely that the real problem at the heart of the accusation and the broad interest it generated was not witchcraft, and although it is reasonable to suppose the real problem had something to do with community solidarity, merely re-stating the first, specific problem in the terms of the second, more general one, did not in itself solve either.

Recent work in anthropology broadly (the title of this article references Urban 2001) and lowland South America particularly (Conklin and Graham 1995; Jackson 1989; Oakdale 2004; Turner 1991 among many others) has addressed the reflexive and self-conscious use of the "culture concept » and reified notions of « culture » both across and within cultures. One of the points I wish to make in the present essay is that this process can also entail ingenious, sui generis deployments of familiar, quite anthropological modes of cultural analysis that aim to decode cultural expression and representation in order to resolve social conundrums. Nevertheless, the Isosenõ case I will discuss here illustrates how a sophisticated engagement with what Urban (ibid.) calls " metaculture " - thought, discourse, and conversation about culture - allows neither anthropologists nor natives to slip the bonds of culture proper.

There is a second point to be drawn out in the present account. With specific respect to witcheraft as a cultural phenomenon that has generated a huge meta-cultural commentary in the anthropological literature, I want to suggest that CABI leaders' failure to resolve the social tensions of which witcheraft may indeed be the cultural expression, is quite similar to anthropologists' collective failure to arrive at a single, definitive account of what the universal social denominator of the phenomenon "witchcraft 》 is across cultural settings. If anthropologists have collectively generated one persuasive insight about witch- 
craft, it is that it participates somehow in interlacing the domain of the sociocultural with the domain of the socio-political. In Isoso, CABI leaders acted according to this very precept. But the stubborn fact is that Isoseño people have entrenched disagreements on both planes: about witchcraft, and about community dynamics. The same, of course, is true of anthropologists. We are unable decisively to " decode " witchcraft because even if it is a code we are not able collectively to agree on what, exactly, it codes for. If we the anthropologists (like they the Isoseño people) all were to think the same things about social dynamics and their symbolic representation, our endless discussions of the problem of witchcraft might well dwindle away. Mutatis mutandis, in Isoso (as we shall see) the community never came to a resolution of this particular case. The meeting ended inconclusively. The specific fates of the ill girl and her accused bewitcher became almost incidental to its denouement. However; the evident vulnerability to criticism of CABI's attempt at mediation was a source of enormous satisfaction to (and further discussion among) meeting attendees. This phenomenon, too, should be familiar to an anthropological readership well versed in the generations-long and perennially contentious literature on witchcraft.

\section{BACKGROUND}

The present report draws on a total of two years' field research carried out in Isoso since 1997. Isoseño people speak Guaraní and take their name from their home territory, « Isoso » - a hispanicization of a Guaraní phrase for " water that goes $"{ }^{1}$. Nine thousand Isoseño people live dispersed in twenty-seven villages strung along one hundred kilometers of a seasonally-flooded river in the Chaco, lowland South America's arid central plain (Figure 1). They divide themselves into an upriver (Alto) and downriver (Bajo) section, with marked rivalries of long standing between the two. Nevertheless, they are (and have been since at least the late nineteenth century) united under the umbrella of the Capitanía del Alto y Bajo Isoso: an entity that today combines elements of a hereditary chieftanship, an elected bureaucracy, and a fund-raising development organization. When I first became interested in visiting Isoso, I was told by an anthropologist colleague that I would have to get CABI's permission if I was serious about carrying out research there. If I did not, I would be thrown out. If I did, CABI's approval would act as what she aptly termed my " passport » in the community. This was true. Isoso is akin to a small principality: it maintains external relations, controls travel and trade within its borders, and is led and represented by a closelynetworked, semi-hereditary elite (Combès 2005; Combès and Lowrey 2006; Combès and Villar 2004; Lowrey 2003).

Since the nineteenth century, Isoseño have combined long-standing practices of maize agriculture, fishing, and hunting with seasonal wage-labor migration to 

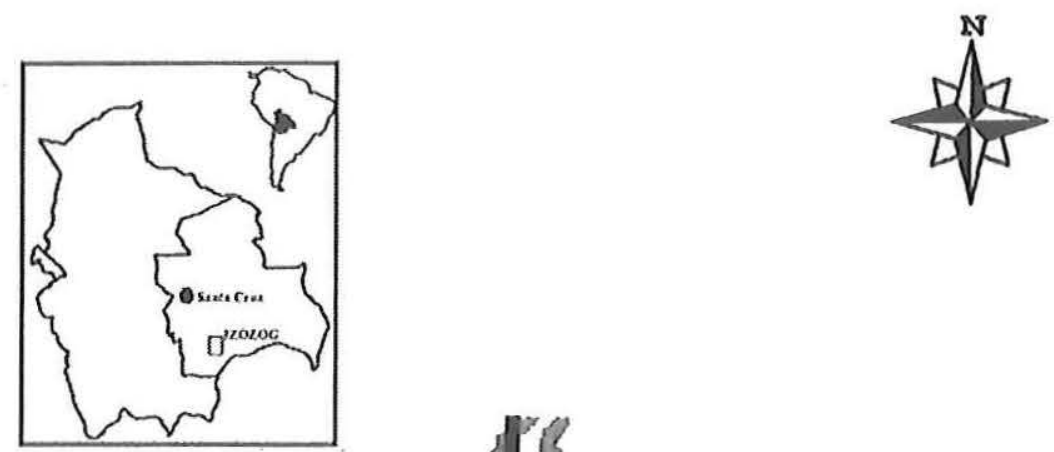

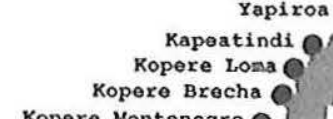

Kopere Nontenegro $\mathrm{O}$

Kopere Guasu of

Karapari O

Isiporenda $C$
$30^{*}$

FIG. 1 - Isoso and its villages 
create their way of life. In the mid-1990s, Isoseño began also actively to pursue projects that might provide more regular salaried employment to community members. Most of these revolve around the local environment, local culture, or local identity and are funded multilaterally by grants, loans, or other foreign aid. During my fieldwork, I followed the Isoseño experience with two such projects. The first was an attempt, funded jointly by the French and Bolivian governments, to build a small laboratory adjacent to the house of an Isoseño paye (shaman) and - or so went the hope - to process traditional medicinal plants into commercial pharmaceutical products. This project was not a success. The second, funded by the United States Agency for International Development on a much larger scale, was an initiative to integrate Isoseño practices with conservation science in the management of the 3.4 million hectare Parque Nacional Gran Chaco, established in 1995 (for a detailed account of the two projects, see Lowrey 2003). The influx of cash and power into the community by way of CABI with this latter project, and a combination of both baseless and accurate rumors regarding CABI's (mis)handling of those funds and that power, form the immediate backdrop to this meeting.

This nemboati was held at around the same time that a series of village-byvillage consultations on the park management plan were being conducted by (primarily non-Isoseño) park personnel. At the time, my understanding of the meeting's dynamics was limited to my perspective from the downriver village (Ibasiriri) in which I was living at the time of its convening. I had only begun fieldwork in earnest several months before. Although I was - as anthropologists are wont to be -interested in witchcraft, I was shy about inquiring into it. In any event, the paye of Ibasiriri, Don Jorge Romero ${ }^{2}$, specialized in treating illnesses caused by the iyareta (forest spirits; literally, " owners of the forest ») rather than those caused by human mbaekuaareta (witches; literally, « knowers »; -reta: forms the plural).

Much to my pleasure and surprise, because his willingness to have me visit and ask questions about his practice had until then been distinctly tepid, one day Don Jorge suddenly asked if I would like to come along with him, his advisors, and the village " captain » (the Spanish military term, capitán, is used to translate the Guaraní word for leader: mburuvicha) to a multi-village nemboati to be held the next day in the upriver village of Kopere. It would be, Don Jorge's advisor Felix Menéndez explained, dedicated to the resolution of a case of witchcraft accusation. The renowned paye Don Miguel Cuellar would be there, as would the mburuvicha guasu ( Capitán Grande ») of all Isoso, Don Bonifacio Barrientos (hereafter Don Boni).

Obtaining the specific permission of Don Miguel and Don Boni-along with the general approval of a pan-Isoso nemboati of leaders - the year before I began fieldwork had been vital to my being allowed to undertake research in Isoso at all. It is quite possible that Don Jorge only invited me in order to learn more about my 
relationship to these two important men. I agreed eagerly, and Felix and Don Jorge told me to be ready in the morning when the mburuvicha guasu's red Ford Explorer (paid for with national park funding) would roll through the village to collect us.

Bursting at the prospect of some genuine fieldwork (the daily tasks I set myself at the time felt like make-believe ethnography), I decided to go and tell Dona Cristina about my plans for the morrow. She was one of the people in Ibasiriri who made me feel welcome during the difficult early months of my time there. In her fifties, she is unusual among women her age in that she speaks very good Spanish. This facilitated our early interactions. A well-respected woman advisor to the leader of her village, Dona Cristina is also very kind. At her household lived what may have been the only fat dog in all of Isoso, a half-blind mutt that never strayed far from her hearth.

When I arrived that day, I found her in tears. She was surrounded by both male and female kin. Although it was mid-afternoon, her husband, whom I had never met before, stood at her side. Usually when I would drop in during the day, Dona Cristina and a daughter or friend would be working together; her grandchildren, husband, and son-in-law came home only for the midday meal. Flustered because I couldn't imagine I was welcome, but not wanting immediately to depart without expressing some kind of comfort, I sat awkwardly when invited. I apologized for my ill-timed visit, and said I just wanted to let her know I would be going to a neighboring village the next day. "That's it! That's it! », she cried. " They are saying my poor sister is a witch, and now they want to burn her. They got a [non-Isoseño] spiritualist from Santa Cruz to accuse her, none of the payereta here said it. She married a man from that village and is there all alone, she has no family with her. I want to go tomorrow with the mburuvicha guasu Don Boni if there is room in his vehicle ».

Though I in fact had no idea what would transpire the next day, I insisted « They won't harm your sister. They don't do that anymore. Don Boni will calm everyone down ". Unfortunately, even I knew very well that as recently as five years before an elderly couple accused of witchcraft had been shot and their bodies burned (rather than buried) in a village far downriver. However, I also knew that $\mathrm{CABI}$ - mindful of its good reputation as a partially modern, partially traditional institution - conscienced only banishment as the maximum sanction for witchcraft ${ }^{3}$. The killing of the couple in that downriver village (and of a man accused of witchcraft and shot in an ambush in the village in which I was living) during the early 1990s were decisions undertaken at the village or even villagefaction level, without community-wide consultation.

Banishment, theoretically permanent, is often in effect temporary. A person may be expelled from a particular village, or from all of Isoso, or even from Bolivia (northern Argentina - where a related community of Guaraní-speakers is located and where many Isoseño people have relatives - being the prescribed 
destination). Of the eleven 1990s-era cases of witchcraft-accusation that resulted in public action and about which I know, in seven instances the accused were banished. In at least five of these cases, the banished persons later attempted to return to their home villages and in four of these instances were again the subject of accusation. Isoseño people have too little income to live easily outside their kin networks. In addition, although everyone has relatives outside their own village (or in the nearby small town of Charagua, or in the lowland Bolivian city of Santa Cruz de la Sierra, or across the national border in northern Argentina), these kin can be reluctant to take in (or simply too poor to support) relations who have been rejected elsewhere. Therefore, banished persons frequently press for « right of return » or at least attempt to obtain tolerance of it.

In any event, Doña Cristina's husband, grim-faced, seconded my platitudes. He assured her that I was right, that Don Boni would calm everyone down, that no harm would come to her sister. During this interaction, I became concerned that Doña Cristina and her family might think I had come by on purpose, in order to pump them for information. Although I was afraid it would appear rude to leave abruptly, I also did not want to give the impression of hanging about listening. I repeated myself: «I didn't know it was your sister. I am sure Don Boni will calm everyone. I am sure she will come to no harm ». I then apologized again for my ill-timed visit and took my leave.

Returning home, I headed for the village central clearing (a large irregular space which includes a soccer field at one end and a shady space for holding meetings near the center). As I neared its edge, Doña Amelia spotted me and waved me over to her hearth. She lives close enough to Doña Cristina's that they can each tell who might be visiting the other, but too far to overhear conversation.

Village layouts in Isoso are higgledy-piggledy but not unmotivated. In upriver (Alto) Isoso - where Ibasiriri and Kopere are both located - homes are clustered in bunches according to kinship, but with none of the bunches being very far from the others. The collective effect is a cozy rabbit-warren feel in the villages. In downriver (Bajo) Isoso, village layouts are similarly meandering but with much greater distances between homes and, consequently, relatively much more privacy in individual households.

Doña Amelia, a widow, is in her seventies and is perhaps the most eminent woman in the village. She is a member of a hereditarily powerful family. Like Doña Cristina, she is an advisor to the village capitán in Ibasiriri and also like Doña Cristina sometimes travels to other villages for ñemboati to represent her village or to follow topics in which she is interested. Their personas are strikingly different. They sit together and chat amicably when at outside meetings, and their respective households are located in distinct but adjoining clusters. Nevertheless, there is not much visiting between them when they are in Ibasiriri.

On this day, after I greeted her and took the seat she proferred, she asked if I'd just been to Doña Cristina's. « Yes, poor thing! » I replied. « I didn’t know about 
her sister, that they say she is a witch. She is crying, now I am very embarrassed to have paid her a visit at such a bad time ». " That's right! » Dona Amelia replied with fierce glee. " She's a witch, and they're going to burn her! ». " But they don't do that anymore », I protested, " they just eject them ». Dona Amelia shook her head: « Oh, but they've done that twice before with her! She just came back after seven years of living in a neighboring village. No, the payereta are going to have a yembosingaru guasu ${ }^{4}$ and then they are going to burn her ». She then gestured toward the hearth in case I missed the point.

This was startling. As I came to learn more about witchcraft in Isoso, Doña Amelia's reaction became more understandable (if still uncharitable). When discussing their own experiences with witchcraft, when they or someone they know personally has been made ill, Isoseño almost always will suspect specific others of being witches and of having caused the sickness out of envy or spite. However, when discussing witchcraft in general, Isoseño say witches are compelled to harm others and that they find their victims capriciously, that this is the only way witches can be " happy » and live " tranquilly ». Some people will go so far as to say not all witches are malicious by nature, and that they simply must find victims whether or not they personally want to harm them. Their mbaeruvi, a semi-volitional witch-substance contained in their bodies, impels them (for more on the mbaeruvi, including possible etymologies, see Lowrey 2003, p. 183 note 11).

Mbaekuaareta, then, lurk among us; they are dangerously unwilling (or unable) to control their capacity for harm and for that reason it is the duty of the community to get rid of them once they've been identified. If someone is made ill by a witch, no-one suggests the victim could have done anything to prevent it ${ }^{5}$. When I asked people how the mbaeruvi was transmitted from witch to victim, I received various answers, none of them mutually exclusive but also not fitting logically together. The mechanisms of witchcraft are not the subject of much speculation. It is the fact of witchcraft which is intensely interesting to everybody. It seems to operate much like Latour's " black box » in science: " only the inputs and the outputs count » (Latour 1987, p. 3).

Because there are no sure diagnostic tests for witches, a ñemboati may be held as a kind of public trial. The accused may or may not be present to defend him/herself (according to the data I gathered, men and women are accused of witchcraft with more or less equal frequency). Minimally, the village mburuvicha must be present, and payereta are usually invited as « expert witnesses ». Payereta know who the witches are, though they don't always choose to reveal that knowledge. If a consensus is reached, a decision is written in the community « Libro de Actas » (minutes-book; each village has one which records the proceedings of important ñemboati in a mix of Guaraní and Spanish) and a decisive majority of community members must sign the decision (a mark suffices for people who are not literate). The outcome of such assemblies is by no means assured. People accused of witchcraft are not always, or even usually, social 
outcasts. Judging by the cases about which I have direct knowledge, a strong showing by either accusers or supporters can carry the day. Finally, any collective decision is subject to both private and public revisiting.

\section{A SEason of witchcraft?}

The case of Doña Cristina's sister was not an isolated one. Soon after my arrival to Isoso, Don Martin, an elderly man who took to dropping by the house where I was living for tea and rolls and a chat, told me about the sudden death of a young woman in the village. She had complained of a headache in the morning, made the midday meal, and then dropped dead in the afternoon - leaving behind her husband and two small children. Everyone was very shocked, he said. Eventually I worked up the nerve to ask if anyone supposed she might have been killed by witchcraft. "Witchcraft? » Don Martin repeated noncommittally, " witchcraft, mmm, I don't know about that. No one can understand why she died ».

In the months that followed, I heard about other witchcraft problems: Don Jorge was often going to an upriver village to treat the maize fields there, which were plagued by worms. Several boys and young men in the neighboring village had been taken ill and a prominent woman in the community was accused of bewitching them. In Isoso's central village, a man who had been expelled from the community for being a witch in the past, and had recently returned, was expelled again.

Eventually, I was filled in about events in my own village that had taken place while I was away for the Christmas holidays. A villager, a man in late middle age, had become extremely ill. In his feverish ramblings, he confessed (it was said) that he was a witch and he began recounting all the people he'd killed across the years. The list included the young woman who had died a few months earlier. The villagers of Ibasiriri held a meeting at which " even his own [adult] daughters » renounced the sick man, saying they hadn't known he was a witch and were now prepared to wash their hands of him. These two elements, it turns out, are common features of recounted witchcraft stories: confessions by the supposed witch, and renunciation of the witch by his or her immediate family. I have never heard a first-person account of either sort. Don Boni, the mburuvicha guasu, was asked to come with his vehicle and transport the man out of the village to the mini-hospital in the main village, where he died (it was said) raving, alone, and unvisited by friends or family.

Because I was always the last to hear them, I never gained any sense of how witchcraft stories travel among Isoseño: that is, how it is that rumors coalesce around some people and not others. I always heard stories in conflicting versions, elaborated with what struck me as multiple layers of baroque flourishes. I could 
not identify a sociological pattern to accusation. Some accused people were men; some women. Some were old; some were young. Some came from powerful families and/or had prestigious personal standing and deep ties in the community; others were of low standing or had only come into the villages where they were accused by marriage (which is not, in itself, a prejudicial condition: the well-respected mburuvicha of Ibasiriri is a resident-by-marriage, as is the paye Don Jorge). This is not to insist there is no pattern; only to admit that if one exists, it remained obscure to me.

It may also be the case that witchcraft accusation itself comes in waves. Hirsch and Zarzycki (1994) document a series of accusations in Isoso in the late 1980s that closely mirrors the one I encountered the late 90 s. It was also centered in Alto Isoso, with accusations in the same set of villages in which accusation flourished when I was in the field, and eventually required the intervention of the mburuvicha guasu. Hirsch and Zarzycki analyze this earlier flurry of accusation in terms of community factionalism generated by disagreements among evangelical sects and between evangelical converts and traditionalists in Isoso. Certainly, these divisions also animated the climate of witchcraft accusation I witnessed, though the worldly relationship of CABI to outside powers seemed more immediately in play.

\section{Account of the Assembly's Unfolding}

I began waiting for Don Boni's red Ford Explorer at 8:30 in the morning. Don Martín, dejected, had gone home after coming over for breakfast: he, too, had wanted to go to the nemboati but been told there would not be room for him. Much to his quiet hurt, Don Martín had been substituted as advisor to the paye Don Jorge two or three years earlier. A younger man, Felix Menéndez, had taken his place. The change was made after Don Jorge's other advisor, a man who had been the paye's dear friend, companion, and was known as a payerai (« little» - as in less powerful - paye) himself, suddenly died. That man's son, Hipólito Cayaguiri, had taken over his father's duties and at the same time Felix Menéndez - Hipólito's contemporary in age - replaced Don Martín. Hipólito and Felix Menéndez are both part of a younger, better-off, more worldly generation than is Don Martín; in recent years, it is likely Don Jorge came to want more of the kind of support and advice these younger men could offer.

I waited for hours, becoming more and more anxious. Perhaps like Don Martín and (as it turned out) Doña Cristina herself, I was to be left behind: unwanted, too unimportant to ride in Don Boni's late-model SUV. Don Boni's red Ford Explorer, tape deck playing Guaraní drum and flute or regional cowboy chacarera music, perpetually rides overloaded. After becoming mired overnight in a muddy rut on the dirt road to the regional capital, Santa Cruz de la Sierra, placards were placed on the dashboard of each CABI vehicle stating that the 
operator could not drive with more than ten people on board. The placarding is emblematic of how many people may lay claim to " getting a ride " from CABI, and how inadequate CABI's resources are to the task of satisfying all such claims.

Finally, close to two in the afternoon, Hipólito Cayaguiri came by on his motorcycle (of which he had use as part of his job as a field agent for an NGO forestry project). He explained that CABI had had an « internal » meeting, just for leaders, all morning in Isoso's central village but that now the open ñemboati would be getting started upriver. We set off together at high speed, traveling the road that connects the twenty-three of Isoso's villages that are located on the west side of the river (four villages are on the east side).

As we neared our destination we began passing groups of people on foot walking toward the meeting site. Once we arrived, to a large clearing next to the home of the village mburuvicha and under the spreading canopy of several tall locust bean trees, I saw that there were about two hundred and fifty people in attendance with more arriving. This was a large ñemboati by Isoseño standards. Most single village meetings are attended by a dozen to several dozen residents.

Much to my relief, the mburuvicha guasu Don Boni greeted me warmly and kept me at his side. The most important of Isoso's payereta, Don Miguel, nodded gravely when I caught his eye though he did not speak to me. Before the meeting began, assembled visiting dignitaries were served a meal of rice and beef stew. CABI had purchased and butchered a cow for the event. We sat in groups of about a dozen; three or four seatings were necessary to serve all the village leaders, advisors, and other important visitors. The non-dignitary attendees stood at a distance, chatting during the meal.

Finally, close to $3: 30$ or 4 p. m., the meeting began in earnest. I was surprised when Don Boni called me to sit on his immediate right; seated to my right was his son-in-law Elio. Elio, in his mid-twenties, was at the time serving as Isoso's first deputy mayor (sub-alcalde) a position created by a 1994 administrative decentralization of Bolivia's government meant (among other things) to empower traditional indigenous forms of governance.

Elio also held a position with the national park as an «environmental educator ». This meant he - close kinsmen to the mburuvicha guasu - drew two monthly cash salaries in a community in which most people draw none. Salaried and leaderly positions " cluster » in Isoso around ties of kinship and friendship (Combès 2005; Combès and Villar 2004; Lowrey 2006). Being left out of these inner circles of influence and largesse can be personally sad-making: as with Don Martín, the former advisor to the paye Don Jorge who was left behind that day. It can be individually disadvantageous: as with Doña Cristina, the sister of the accused who had every reason to expect to have been included in the day's events but was also left behind. But at a community-wide scale, these concerns about legitimate inclusion and exclusion are the single greatest source of political conflict in Isoso. 
There are, of course, many reasons why Don Boni may have chosen to sit me to his immediate right for the proceedings. Perhaps it was a kindness to a lost-looking giringami ${ }^{6}$ beginning her fieldwork. Perhaps it struck him as an opportunity to curry favor with an outsider who might one day become a useful ally ${ }^{7}$. However, I suspect his principal rationale for seating me at his side had to do with CABI's self-reflexive consciousness about representation, in the community and out of it. I represented, in miniature, the community-external audience to which the CABI leadership itself is continually attuned. At the same time, at the meeting I was a displayable emblem of that larger audience to the rather smaller audience composed by community members. When the CABI leadership calls for solidarity, they often do so specifically in terms of a solidarity vis-à-vis the "outside world» that requires the setting aside of community-internal divisions. Because this was to be Don Boni's strategy at this meeting, it may have struck him as useful to have a minor token of that outside world sitting both at his side in literal terms and under his thumb in more figurative ones. By way of various ostentatious gestures during the meeting he played solicitous paternal patron to my role as flinchy, unsure, filial client.

As people settled down for the meeting, I was surprised by the amount of side-talk and joking (at least by the leaders), because I anticipated a tense atmosphere. The community members in attendance sat or stood (as is common in such meetings, many village residents brought along their own chairs) in loosely sex-segregated clumps, forming a large irregular circle that was severalpersons deep in most places. All ages of adults were represented but no children were present. This was unusual, as children are otherwise wont to wonder in and out of meetings at will, crawling up on to the laps of their mothers, fathers, grandmothers or grandfathers for a bit of attention and then sliding off again when things become dull.

The meeting opened with a brief speech by Don Boni, followed by one from Elio's father (the mburuvicha of Alto Isoso). The meeting secretary then rather perfunctorily read the minutes of a previous meeting dedicated to the same case, at which the young Bolivian doctor serving at the mini-hospital in Brecha had emphasized that the ill girl's symptoms were likely caused by a uterine tumor, not witchcraft (the doctor had since finished his term of service, and was not present). At this stage of my time in Isoso, most of the business of meetings like this was beyond me. My Guaraní was equal only to slow, face-to-face conversations with lots of redundancy. Elio whispered translations to me at pauses in the proceedings.

Don Boni called out the name of each of Alto Isoso's villages in turn. In a couple of instances, no one responded. This caused murmurs of discomfiture, for reasons to which I will return further on. For each village represented, the village mburuvicha or his deputy would speak first. They had all been at the " internal meeting " in Brecha beforehand, and, one after another, gave essentially the same 
speech: «I cannot say this or that person has done harm. I depend on the community, and on the Capitanía, to come to a resolution. But I on my own cannot say who has done harm $"$.

Because I attended very few multi-village meetings of this type during my fieldwork, I cannot say if this was a formula settled upon during the « internal » meeting or if conceding authority to the community and the Capitania is a conventional gambit at all such multi-village meetings. I suspect the latter ${ }^{8}$. In the case of several villages, the mburuvich a was the only person who spoke up; for others, however, fellow attendees from that village would speak after him. Doña Cristina's sister, who was present (looking miserable), did not speak, nor did the ill girl (who was also there, looking similarly despondent). The ill girl's father spoke briefly and angrily. Elio did not translate what he said. At one point, an elderly woman who was a relative of Don Boni's gave a rather long speech involving her arm that was interrupted several times with appreciative laughter. I asked about it later. A man from my village explained:

She said, « you all won't believe it now, but I was beautiful when I was young! There was a man who wanted me, but I didn't want him. He got very angry, and because he was a witch he knew how to injure me. He caused me to have a problem with my arm. But I knew what to do, I just went to the payereta here in the community, they knew how to cure me, and they easily took care of my arm $»$.

At the end of each speaker's contribution, whatever its content, Don Boni responded enthusiastically: ikaviyae! [« very good! »]. This kind of showy affirmation is unusual. The normal reaction to others' speech in such meetings is respectful silence or (at most) emphatic nodding.

One of the last community members to speak was Hipólito Cayaguiri, who had brought me on his motorbike. He said,

It has been more than a year since my father [the former advisor to the paye Don Jorge] died. I also cannot say such and such a person has done harm. I can only rely on our payereta, our capitanes, their asesores, and the community to reach a decision - as I did when my own father died.

Finally, Don Boni asked the paye Don Jorge to speak; he declined. Then he turned to the renowned shaman Don Miguel and asked him to speak. Don Miguel is Don Boni's kinsman, and lives in far Bajo Isoso, not in Alto. He said,

Jorge, Eustaquio [a very old shaman who was not present; also from Bajo Isoso], and I are organized to serve the community, to defend it, in concert with the Capitanía. We ask you please to come to us with your problems. If you ask, we will undertake the care of this sick young woman. We will see if hers is a case « for us » [ie, witchcraft] or « for the doctors ». But we cannot accept the word of a paid spiritualist from Santa Cruz; those people may deceive in exchange for money. We payereta serve all Isoseño, we don't ask if they can pay. If we ourselves have not been asked to investigate, we cannot 
accept the word that has been paid for of a spiritualist who says that such and such a person has done harm.

Don Miguel spoke confidently, but softly, with his hands on his belt and frequently directing his gaze to the ground. Although he was a wit and excellent storyteller (as I came to learn when I went to live at his household several months after this meeting), he always spoke in such a manner that one had to be attentive, and lean in, to hear him. This is not the common manner of public speaking for other adult men. Whether skilled orators or not, when men stand to speak they take up a firm stance with their legs slightly apart, speak loudly, and turn at the waist if necessary in order to be able to address the entire audience. They also may bark out jokes or commentary during ñemboati while remaining seated. If Don Jorge or Don Miguel come to meetings in their home villages (they usually do not), they are reserved and speak softly to their nearest companions, if at all. Payereta do not usually speak publicly unless specially importuned, as in this instance, to do so.

Don Miguel's discourse effectively closed the meeting. There were a few more remarks by Don Boni but as far as I could tell, no decision had been reached. Everyone present was invited to sign the acta (minutes) of the meeting. Less than one hundred (that is, no more than one-third) of the people in attendance filed by to do so. Afterward, a group of men including Don Boni and other leaders went to sit slightly apart from the meeting area. Don Boni invited me to join them. No one discussed the meeting that had just taken place. Conversation turned immediately to joking and other topics. However, Felix Menéndez, the paye Don Jorge's advisor, came over and asked me what I'd thought. I said that although I had not understood everything, I was impressed by the calmness of the proceedings and the fact that everyone had had the opportunity to air their opinions. Felix Menéndez then said, "Yes, but it was not a success. At least ten to twelve people from each community should speak if a resolution is to be reached. There was not enough participation ". I asked why people had not spoken up. Clearly vastly more people had been in attendance than had volunteered their thoughts, and the majority of speakers had been CABI-associated in one respect or another. Felix shrugged but did not answer. The meeting had indeed been oddly brief, given all the build-up. It was not yet dark when Hipólito and I returned on his motorcycle to our village.

\section{DENOUEMENT}

When Hipólito dropped me off at my house, he uncharacteristically lingered to chat. He ended up staying for more than two hours, telling me the story of his father's, his wife's, and his own victimization by witches. Hipólito is a pillar of village life. He gets along famously with the CABI leadership, and had at this time 
also been employed for years by a development NGO running agroforestry projects in Isoso. He owns pigs and goats that he periodically sells to trucktraders that drive through Isoso during the dry season. His fields are the muchcommented upon marvel of his village: large, beautifully maintained, full of cultivars exotic to Isoso like tomatoes and peppers, and yielding an impressive annual harvest. His children are many (ten, at that time ranging in age from 2 to 20), his marriage is happy, and he makes his one son-in-law work as hard as he himself does in his fields. He is certain to eventually have more such labourers: eight of his children are daughters ${ }^{\text {? }}$.

The bane of Hipólito's existence is his widowed father-in-law, Martín, whom Hipólito says « just eats ». Once Don Martín had me snap a photo of him, standing in Hipólito's fields, holding a hoe. Martín said, " when my grandchildren see it, they'll say, 'oh, look at our poor grandfather working so hard' ». Hipólito got hold of it as well, and shouted with laughter behind his father-inlaw's back: « look at him pretending to work! He made you take this photo, didn't he! ». Until that day, I hadn't known Hipólito's own father had died just the previous year. I wondered if for that reason Don Martín's hold on life grated on him all the more. That evening, Hipólito told me his father had been hardworking and vigorous until the day he died. As much as Hipólito asked him to slow down he wouldn't, sneaking out with his young grandson to fish and to work in the fields. The morning that he died, he'd been out picking limes and was walking back to the village when he suddenly collapsed. When Hipólito was notified and went to help carry back the body, he saw that: « My father had fallen so forcefully that he had earth in his mouth. I was enraged, I knew then that it had been a witch. I wanted to find and kill the witch immediately ».

Hipólito went to Don Jorge, to whom his father had been both advisor and close friend, and asked him, "Is there something? » [ie, was it witchcraft?]. At first, Jorge did not want to answer but he later confirmed to Hipólito, « There was something ». Hipólito was beside himself. He begged Jorge to reveal the witch's identity and berated him when he refused. Hadn't his father been his friend? Didn't he miss his presence? Who was going to talk to him and keep him company now? How could he not want revenge? Hipólito summed up: « Jorge told me, 'have patience.' But I was not in agreement ».

Both before and after his father's death, Hipólito himself also had dreams that are diagnostic of witch-attack: being chased by a jaguar, or a bull, or a human figure whose face is obscured because a jaguar or bull's head is in its place. This is the witch, attacking but keeping his/her true identity secret (although sometimes people say they do manage to descry the witch's face in their dreams). Hipólito did not become ill, however: « it never failed, in the dream, that as the [attacking figure] came closer, I would find a knife or gun in my hand, or someone would hand me a knife or gun, and so at the last minute I could save myself from harm ». 
After a while, the frustrated witch himself had the nerve to drop by Hipólito's house and ask, feigning neighborly interest, « How are you? Have you been ill? Has your wife been ill? » Hipólito answered, " We are well. Dios es grande (God is great), he watches over us ». Hipólito is not an evangelical Christian, and I was surprised to hear this invocation of the Christian God's power over witches from him. He went on to invoke the phrase again at the end of his story:

So, then, after my father died and I was so angry, I did not want to have patience as Jorge advised. But, God is great. That witch eventually became very ill and swelled up and died alone. He had killed many people! It was the one you heard about who died over Christmas: he was the one who was attacking me, who killed my father, who killed that young woman last October. Don Jorge was right, you have to have patience, God is great. That's why I spoke today at the ñemboat $i$ in Kopere, to explain to people that they should have patience and accept the counsel of the payereta.

Clearly, people refer problems with witchcraft to a variety of authorities and regimes of morality and knowledge. These include different (often rival) local payereta; medical doctors; city espiritistas; and sometimes the Christian God. The patient may otherwise be quite skeptical or at least ambivalent about some or all of these. Given that in Isoso accusations of witchcraft are common but quite unpredictable, and attacks by witches common but quite unpreventable, a speculation put forth by Jeanne Favret-Saada (1980, p. 186) in reference to witchcraft and « unwitching » (in 1970s rural France) seems relevant here:

I have never heard a bewitched person complain to an unwitcher of having been accused of being a witch; indeed, none of the many stories I was told contains this situation which, however, cannot be a rare one, since every time someone considers himself bewitched, he has to name a witch: so there are as many witches as there are bewitched. The problem, then, is to know how this large number of accused people deal with this imputation, since they at least know they are innocent.

Now, in Isoso there are not exactly as many « witches » as " bewitched », since many accusations can accumulate against a single person. But it is also the case that different people also have idiosyncratic, highly personal opinions about witches, so that many people are suspected by at least one other person. Bewitchment is a proof of innocence: witches do not attack one another. At the same time, a person who says s/he is bewitched is not necessarily believed by everyone. At this point, one begins to see that sets of accusations and counter-accusations, protestations and judgments, are in constant circulation, which in everyday practice (trials-by-ñemboat $i$ being rare) are evaluated with respect to a manifold array of standards (and loyalties).

Hipólito laughed as he took his leave:

I have told you so much, now you are going to be frightened, thinking here you are by yourself in Isoso and it is full of witches! Now you are not going to be able to sleep alone in that house, you should have one of my older daughters come and share it with you. 
Hipólito knew, because he works with APCOB, that Bolivians from the city and foreigners tend to consider witch stories " scary » (if also somewhat implausible). However, over time in Isoso I found that Isoseño do not consider witchcraft frightening so much as they do angry-making (in this as in many other respects, witchcraft in Isoso resembles witchcraft as documented by Edward Evans-Pritchard among the Azande [1937]). What right does a witch have to cause harm to anyone, just so he or she can live « happily? » More specifically, what right does a witch have to react to my happiness, good fortune, romantic preferences and conquests, or natural gifts, with malicious envy?

This relates, although not in a particularly illuminating way, to the sociology of witchcraft. Some anthropologists (Hirsch and Zarzycki 1994; Riester 1986) have explained witchcraft in Isoso as a mechanism for social leveling. If people believe others' envy will cause them misfortune, they may try a bit harder to share or be cooperative so as to avoid witch attack. Based on my field research, this strikes me as unpersuasive on two grounds. First, no one ever spoke to me about preventive measures relating to witchcraft. People would say « if you have a little something, lots of people will want you to share, and if you don't, they might get angry and if they are witches try to harm you. » But this line of reasoning never ended « therefore I try to share, thereby avoiding attack ». Rather, the reasoning seemed to be that nothing ever satisfies a witch.

Second, just as there was not an overarching pattern (that I could discern) to accusation, there was not a pattern to victimization. I never met a person in Isoso who considered his or her position so pitifully unenviable as to render him/her immune from attack. Instead, people's stories of witchcraft persecution were very regularly prefaced with ostentatious declarations of becoming modesty about their considerable fortune and charms: «I don't understand why a witch would attack me, perhaps just because I have a few animals » " perhaps just because I have such productive fields " " perhaps just because I worked so hard and earned so well at the zafia » " perhaps just because I chose to marry person $\mathrm{x}$, breaking the heart of person $y$ » etc. This, I think, helps to explain the co-existence of general and particular causal explanations for witchcraft: the witch who is attacking me is a specific person who envies or wishes me ill in a specific way. Witches in general, though, may also attack others (who don't necessarily merit envy or malice in my view) because that is what witches do. As a good community member, I support getting rid of witches either way: unless someone I know not to be a witch is accused, in which case I will publicly argue that in this instance a malicious or misguided false accusation has been made. 


\section{WHY WITCHCRAFT?}

The question therefore remains: why witchcraft? If we anthropologists believed witchcraft acted in exactly the way our informants tell us it does, this question would not pose such a knotty problem for the discipline. However, " translating » it into terms of malice, envy, or interpersonal conflict assumes we do know exactly in what these latter domains consist and take form. That these categories also are subjects of anthropological investigation is part of what makes witchcraft a topic of perennial interest to the discipline. After all, if we are puzzled by witchcraft, we are at a total loss when confronted with the problem of how to clearly distinguish « etic » and « emic » definitions of basic categories of human motivation like malice, envy, and desire. This is, it bears emphasizing, a virtue of the anthropological approach. Those disciplines, like economics or evolutionary psychology, that most vociferously assure their audiences and themselves of the rigor of their assumptions in these respects are also least able to discern, let alone account for, cross-cultural variation in motive and aspiration. It is exactly those variable specifics, several of which I delineate below, that best account for the failure of CABI's meta-cultural address of the problem of witchcraft at the nemboati described here.

\section{The occult made ostentatious}

In Isoso, a witch is an mbaekuaa, a « knower ». Many anthropologists have remarked multiple parallels between lowland South American and Melanesian indigenous practices and philosophies. Don Kulick (1992, p. 285) notes that " practices of knowledge throughout Melanesia tend to pivot around an oscillation between concealment and revelation ". This is no less true in Isoso, but here, practices of knowledge participate in a more general dynamic of concealment/revelation: one that is operative across many domains of social life (witchcraft among them).

In fact, considering very diverse exemplars of ordinary and extraordinary practice in Isoso, I began to notice a recurrent motif: that of shadowy transactions, made showy. I will enumerate examples below. The point to be made here at the outset is that witchcraft inverts this pattern: it inheres in secrets not displayed; in riches not made visible; in gifts unshared and in occult debts serviced at the cost of the community. Shamans (the positive counterpart to witches) and good (as opposed to bad) leaders engage in shadowy transactions, but ultimately make them showy. While they do, necessarily, undertake occult dealings - out of sight, knowledge, and understanding of regular people - they later make the outcomes ostentatious.

Perhaps more importantly, like leaders, shamans are well-known public figures. There are no secret shamans in Isoso, though there are very definitely differing 
opinions among Isoseño people about various shamans' competence and goodwill. Shamans - whether they receive their powers directly from the kaa iya reta (masters of the forest) or by hereditary transmission - must be «titled » (the Spanish term titulado is used) to practice, in public ceremonies that both community members and community leaders attend (a good description of one such ceremony may be found in Hirsch 1991). Witches, by contrast, obtain their powers in secret and do their best to carry out their nefarious activities undetected (for more on the origins of shamans' and witches' powers, see Lowrey 2003 and 2006). Nemboati about witchcraft are attempts to end private machinations by bringing them to public light.

Something similar has been happening with leadership in contemporary Isoso. A major source of community complaint about CABI leaders is that people suspect they are failing to carry out the " revelation » part of this iterative formula of Isoseño social life. Like shamans who visit otherworldly locales, CABI leaders are expected to visit distant and mysterious, albeit this-worldly, locales (government buildings, urban offices, even foreign countries) in the course of their work. Isoseño take pride in the fact that their leaders do this so often and so well. But increasingly (and sometimes rightly), Isoseño people are concerned that their leaders are not making the results of their effectively invisible dealings manifest. The public outcomes - distribution of largesse, job creation, bringing of new partners (development NGOs, political party leaders, government officials) into Isoso - seem to many Isoseño people to be out of proportion to the secret goings-on. To keep the results of one's transactions as hidden as the transactions themselves is to behave, more or less, like a witch (see also Lowrey 2006).

\section{Ipöra: Display in everyday life}

Ipöra in Guarani means both beautiful or pretty, and adorned/adornment ${ }^{10}$. The literature on lowland South American societies is replete with examples of the importance of bodily decoration and adornment to conceptions of beauty, completeness, and full humanity in the region. In Isoso, traditional modes of bodily adornment are remembered, but no longer practiced: old people recall, from their childhoods, old men who wore the tembeta (labret), a few very old women have filed teeth, and even people in their early thirties vividly describe the costumes and masks that used to be worn by dancers during the arete guasu (harvest festival - literally " great celebration 》- no longer practiced in Isoso, although it is still observed in related communities in Argentina and Paraguay).

All of these bodily markings make visually manifest the expressive and relational capacities of their bearers ${ }^{11}$. Into the early twentieth century, adult men - all of whom were potential public orators - wore labrets that varied in size and beauty in correspondence with their capacities as speakers: and, by implica- 
tion, as social actors (see also Seeger 1975). Today, the markers are different but still present.

Every adult man carries a vokö (see Figure 2) slung from his shoulder or across his chest. This is colorful hand-loomed wool or cotton bag, woven by a close female relative (mother or sister for young men; wife for older ones). The designs are idiosyncratic, combining traditional motifs in innovative ways: women receive design inspirations in their dreams. The yarn with which these are woven is almost always a purchased commodity. Neon-colored yarns are currently very popular. The best bags have multiple full round tassels at the corners and hanging from the cover-flap, which may itself be emblazoned with the owner's name woven into the design (further emphasizing the vokö's personalization). Dependent old widowers (like Don Martín) make do with tattered old vokös made long ago by their deceased wives, or may even be reduced (in a poignant icon) to substituting half of a plain woven saddle bag, knotted where it tore loose from its mate. In Peircian terms, a man's vokö is an indexical icon (Peirce 1955): its idiosyncratic design figures him, the skill and care with which it is woven speaks of the relationships that surround and support him, and the cost of the yarn used suggests something about his wealth. Its everyday use offers both a public and a familiar display.

Nowadays some women too carry vokös. Those who do so are either young women from privileged families who attend one of the boarding high-schools located in two Isoseño villages, or adult women who have been appointed to salaried positions with CABI or an NGO. In part, this is a manifestation of ethnic pride in contexts of dealing with outsiders. However, it is also a claiming by women of the badges of public status more commonly deployed by men.

On outings, young to middle-aged men sport, along with their vokös and depending on their ability to earn cash income, some (or all) items from the following list: neatly pressed jeans; immaculate button-down sports shirts (their spotlessness is no small achievment in the alternately muddy and dusty Chaco); satiny soccer shorts; knock-off Nikes; crisp baseball caps; wristwatches and - for those who have truly arrived - gold teeth. As they approach marriageable age, young women decorate their long loose hair with as many barrettes as possible (up to a dozen is not unusual) and gauzy bows; they wear high-heeled plastic sandals (in place of the more usual flip-flops) and add perhaps a single necklace. Married women, by contrast, almost always have their hair up in a loose bun but add a few more bead necklaces. Old women and widows - unless they are very poor - wear multiple bead necklaces in layers but cover their hair with white kerchiefs.

Life stages, then, are visibly marked in ways different than, but reminiscent of, those described by Terence Turner (1980) for the Kayapó in his keenly observed essay, « The social skin ». Note, however, that all of these contemporary Isoseño adornments are commodities that require (and signal one's access to) cash 


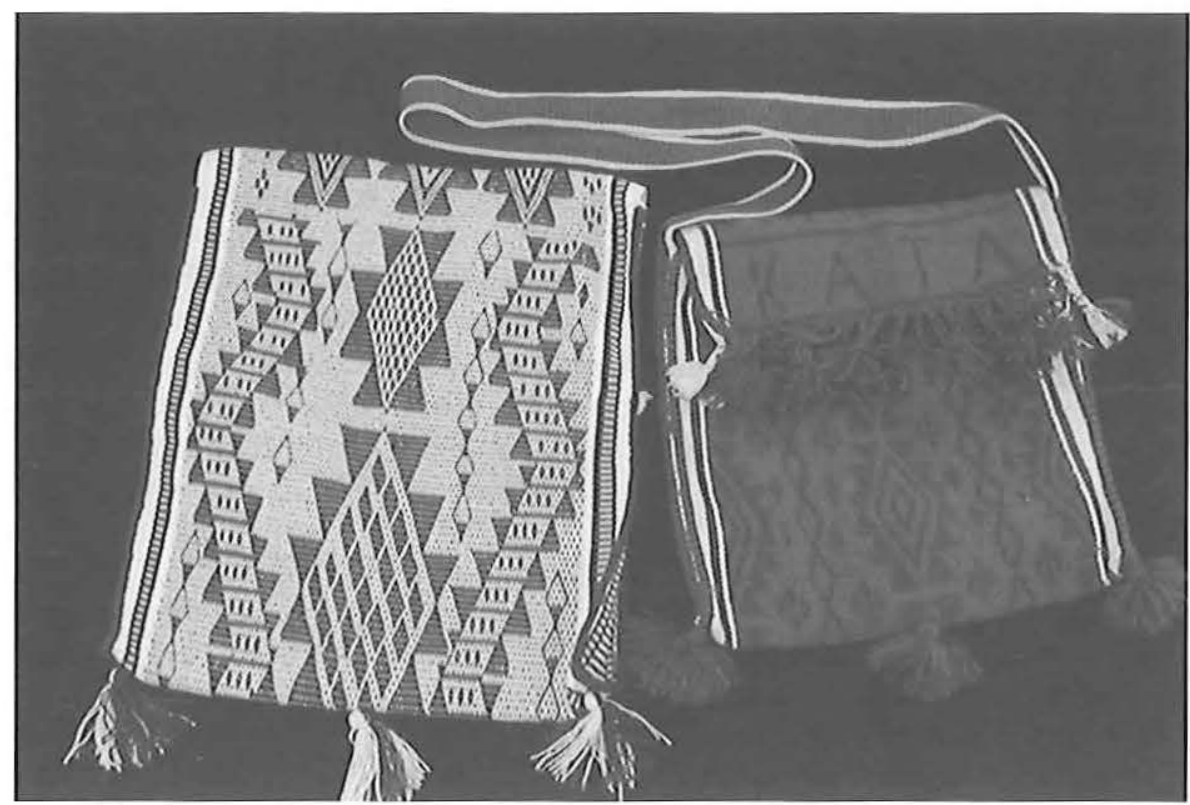

FIG. 2 - Vokös (Photo Courtes y Weber).

income. If the " display » part of the formula I am proposing is easily trackable by naïve observation, what of discerning its « hidden » counterpart in everyday life?

Isoseño people's means of earning money do not involve locally-visible work or transactions. That does not make them « occult », exactly, but there are graded levels of transparency. There are some jobs available to both men and women on ranches and plantations surrounding Isoso, which require them to live near - but outside - their home villages. Limited seasonal work is available harvesting cotton on Mennonite farms near Isoso as well. The major source of cash income for most families, however, is annual migration to the zafra or sugar-cane harvest on plantations to the north of the city of Santa Cruz de la Sierra. Young to middle aged men, often along with their families, spend several months each year outside Isosos, at zafra labor camps. Speculation runs high about how well others may have earned at the zafra. However, everyone knows in what the work consists and can at least guess, based on observing others' industriousness in the fields and the goods they are able to buy each season, how much their fellow-laborers might have earned.

This is far less true of the new activities in which Isoseño involved in the park, or who work at CABI's Santa Cruz offices, carry out. Some of those people spend 
almost the entire year in the city rather than in Isoso, and only their immediate families know exactly what their salaries are. Their work shades over to the kind of completely opaque transactions in which shamans and, certainly, witches have dealings. The shadowy is made ostentatious up to a point: people with salaries are capable of (and carry out) more display. But a continual current of speculation is that these people in fact have more than they are showing.

\section{The personal and the collective}

The elaboration of personal, bodily decoration contrasts markedly to the plainness of living space in Isoso. The utter lack of attention to the decoration of public space and living space is striking in itself, but all the more so because it so diverges from the importance placed on personal adornment. Homes are haphazardly maintained (with some, but rare, exceptions) and essentially without ornamentation (apart from the odd battery-powered clock or promotional calendar hanging on an inside wall). There are no built public spaces in Isoso (aside from those constructed with NGO or state funds, like schools).

Public events also show this unelaborated character. In the arete guasu, masking, costuming, and body painting of persons define the event. There are no constructed displays, nor structures made for the occasion and then taken down, nor other physical transformation of public space. Within the constraints of a generic repertoire, men carve their own masks according to their inclinations and women paint their faces according to theirs (Bossert and Villar 2004).

The pre-eminent public events in present-day Isoseño life are public meetings. $\tilde{N}$ emboati are held in the village clearing under tall shade trees, which are scarce (most vegetation is low, even stunted) and appreciated in the hot, dry, Chaco ${ }^{12}$. Attendees bring their own chairs, and are free to arrive and leave whenever they wish. A small child might wander in to slump against a favorite relation for a while; sometimes the more waggishly friendly of village dogs attempt to lie down in the center of the rough circle of seats unless and until someone decides they ought to be banished. Once one has a bit of familiarity with the meandering layout of Isoseño villages, one may be able to guess the village " meeting space ", but nothing definitive marks it. It tends to be in the shade of the canopy of one or more tall trees, which may or may not be in the center of the village clearing and that rarely correspond to proximity to the homes of prominent village figures. An occasional giveaway is a long strip of metal hanging from the lower branches of a tree, which is clanged to announce gatherings.

The nemboati is an institution long attested to in the historical literature on Guaraní-speaking groups (going back to the sixteenth century) ${ }^{13}$. What people do at nemboati is glossed in Spanish as nivelar la palabra - « to level the word» (Albó 1990; Hirsch and Alberico 1996). This suggests a smoothing-out mechanism that is not, I think, entirely accurate. The Guaraní verb is o(ye)mboyovake: 
" to make reciprocally to face ", which does not necessarily imply confrontation, but that also does not presuppose an integrative function. Nemboati are prime moments - and some of the only moments - of collective revelation in Isoso. Thus the ñemboati is a meaningful institution of long standing, but with very little in the way of material infrastructure to constitute it. The meeting area is kept clear by community labor, but is not visibly engineered to display human artifice. There is no delineation of a markedly geometric circle or plaza as in some other lowland South American societies. Bodies are the sites of elaborate display. Public spaces are, by contrast, effectively naked.

The great exception - that in a sense proves the rule - is cemeteries. These are cleared, maintained, and decorated (especially on the Day of the Dead, November 2nd, a Latin American tradition now observed also in Isoso). However, although the decorating results in a visually striking collective space, it is the aggregate product of different families continuing to watch over, and adorn, the interred bodies of their relatives - at least for a time. Most graves are neglected after a few years (except on the adopted holiday of November 2nd). The exceptions are the sepulchers of dead leaders: another adopted tradition is that of building above-ground plaster tombs, topped with Christian statuary (crosses, angels) over the graves of important leaders. These men were the foci of extraordinary attention and possessors of unusual personal charisma during their lives. Thus, bodies and their capacities (or commemoration of those bodies and their capacities) are the focus of aesthetic attention while the spaces in and through which living Isoseño people engage by and large are not.

The same pattern is seen at the other end of the life cycle. Most marriages are made public by pregnancy and the arrival of children. An intimate relationship is communally ratified not in a collective rite but by a personal transformation becoming obvious. Again, personal statuses and capacities are validated and acknowledged as the visible end to " invisible » chains of processes, events, or predilections. This extrusion, or manifestation, is an important aspect of « positive value creation » (Munn 1986) in Isoso.

These patterns work into the rising number of adherents to evangelical Christianity in Isoso. Hirsch (1991) gives a figure of $70 \%$ in certain villages; in my experience this many people certainly attend culto - evangelical church services from time to time though not all such attendees self-identify as creyente (« believers »). Interestingly, these believers are changing local relationships to public space. In most communities, the largest public building may well be the evangelical church(es) (some communities host two sects). Churches are built using the labor and monetary contribution of their congregations. The trend has been toward ever more enormous hangar-like structures in which variegated attentiongetting decorations are displayed: balloons, tinsel, wall clocks, and satin banners brought from the city. Young creyente couples who aspire to form new families are admonished to avoid clandestine encounters in favor of the public ritual of 
church marriage. If, " traditionally », positive value creation in Isoso was a kind of extrusion, of shadowy transactions made showy, occult dealings made ostentatious, and attached to persons, there is a trend now toward thoroughgoing transparency made manifest in public life and attached to collective structures: one that, for good or ill, is no respecter of persons. This shift has implications for Isoso's « class dynamics » ${ }^{14}$. Evangelical Christianity in Isoso contains within it an oblique critique of the Capitanía. Most of the CABI leadership (although this is changing) are okauvaereta - « drinkers » (meaning traditionalists) rather than evangelical Christian teetotalers - and members of a semi-hereditary closely-knit elite.

In this regard, Isoso does not follow the pattern described for many Amazonian indigenous communities in the 1970s, 1980s, and 1990s, where a traditional leadership is typically (if temporarily) supplanted by Spanish- or Portuguesespeaking "culture brokers » that arise among savvy and/or opportunistic youngsters in native communities (Brown 1993). Ethnography from much of the Amazon (with the significant exception of that on Arawakan groups - and I and others have argued elsewhere that Isoseño society is at least as much an Arawakan society as it is a Guaraní one: Combès and Lowrey 2006; Combès 2005; Combès and Villar 2004; Lowrey 2003) emphasizes a default egalitarian status-quo in Amazonian native communities that may be thrown off-kilter by new dealings. Isoso, by contrast, is a stratified society (albeit on a modest scale). This is not an outcome of recent events, but an ethnographic fact of long import in the community. While young men play important roles in engaging outside organizations, government agencies, and opportunities, middle-aged and older men do too. What is important is that they are almost all kin of some sort (friends sometimes make it into the charmed circle). Age is not a pre-eminent status marker in this community either; nor, to an extent too much discounted in other analyses of Isoso, is gender. Isoseño make their distinctions by other means.

Although envy and ill-feeling over people's very different abilities to outfit themselves with attractive goods is widespread in Isoso, no-one for that reason gives up such display. After all, hierarchies are a part of life here. Display is not subject to censure; instead, hiding one's wealth (or knowledge and powers, in the case of witches) is. Criticism invariably takes the form that so-and-so has more than $\mathrm{s} /$ he lets on. The corollary to this is that inequality is very visible in Isoso. There is evidently nothing censurable, in itself, about a young man wearing flashy clothes in a village where some old people are dressed in tatters. In fact, Isoseño people are articulately ambivalent about the virtues of sharing. When they laud it as a good thing, it is mostly in laments about how there " used to be " more of it. But Isoseño expend rather more energy worrying about the dangers of being too open-handed, generous, and easily taken advantage of ${ }^{15}$. Refusing to share is understandable. People agree that such refusals are sometimes necessary. What 
people really fixate on is what others might have (whether or not they share it) - but are not revealing ${ }^{16}$.

The negation of this, then, is thoroughgoing maintenance of secrecy/ hiddenness: occult processes, transactions, and predilections which are never evidenced nor intended for display by Isoseño persons to the Isoseño public. This is precisely what is troubling about witchcraft: and what has lately been troubling about CABI. People in Isoso are very concerned that some CABI leaders are getting goods, and engaging in relationships, transactions, and processes that they are not ultimately « showing », that is, making manifest to everyone.

\section{Conclusion}

CABI's approach to the meeting was keyed to the fact that it does seem to be the case that witchcraft discourse relates somehow to community tensions. But - and this CABI seemed to miss - it is also isomorphic to them. Just as witchcraft has to do with underhanded dealings kept secret, so those are exactly the concerns people have about CABI. CABI leaders, in the circumstances of the "witch meeting ", confronted only the first aspect head-on: structuring a public meeting that emphasized the importance of submission to approved community authority structures, to tradition, and to the rejection of «outside " suggestions. Leaders and CABI supporters re-iterated the key points: the community, the Capitanía, and homegrown tradition (in the form of the CABI-affiliated payereta) were to be embraced; resolution would surely follow.

February 1999 was an opportune moment for CABI to convene a ñemboati about a " traditional » problem. The CABI leadership seized the day and turned it into an occasion of unity, benevolence (the meal), and enactment of its own " timeless presence » in Isoso (Isoseño strongly criticize the leadership for being absentee, for not keeping abreast of community-internal issues, and for spending vastly more time in Santa Cruz than in the community). Many people may have attended because everyone likes a good thrashing-out of witchcraft histories and accountabilities: the long witch-persecution histories I was told, before and after the meeting and across my time in Isoso, attest to that. But such a thrashing-out was not what people got at this meeting. In effect, CABI attempted to shift the discussion: at a meeting about witcheraft, they discussed community solidarity. Rather than CABI controlling the "direction of analysis» with this move, however, the post-hoc response of community members was to discuss CABI's failings on this front, as well.

Nancy Munn (1973, p. 581) has noted:

In any given [symbolic media-moderated] transaction, this social relationship [the one governing the transaction] is in effect transacted as part of the " message » condensed within the symbols... this social message is co-implied by the symbol vehicles, since in 
any particular instance the relevant relationship is demonstrated by the transaction itself.

At this meeting, there was both a message (about witchcraft, rumors, and insidious threats to personal and social integrity) and a meta-message (about CABI, trust, and community solidarity). Community members were put off by this attempt at translation/transference: but not because they misunderstood it. They got the (meta) message. The point is that they felt just as conflicted about it as they do about witchcraft, for reasons located not in metaculture but in culture.

CABI leaders essentially presented the following deal: if you are concerned with witches, stand with us. Attendees' non-response, I would suggest, underlines that witch-accusation is a problematic of its own as well as being a manifestation of malice, envy, and distrust, to which CABI cannot stand in a clear relation of adjudication because the form of witchcraft is akin to the content of misgivings Isoseño now have about CABI itself. At the time of this writing (2006), several rounds of schisms have taken place in Isoso and the Mburuvicha Guasu, Don Boni, is currently - but probably not permanently - " deposed » (see Combès 2005 for more on the long history of these dynamics). With respect to the denouement of this specific case, the girl and Dona Cristina's sister were almost entirely eclipsed in CABI's framing of the meeting as really about acceptance of conventional structures of knowledge and authority. As of 2004, Don Jorge and Don Miguel reported to me that the ill girl never sought treatment from them. Doña Cristina's sister was still living in Isoso as of my last visit (2005) to the field.

While Evans-Pritchard famously accounted for witchcraft in terms of its " end ${ }^{17}$, recent analyses of witchcraft have nearly exclusively sought to demonstrate not that it performs a function but that it codes for and is coded by other social problems: almost always, the ills of modernity and/or capitalism (exemplary accounts include Comaroff and Comaroff 1993, 1999, 2000; Geschiere 1997; Taussig 1980). In part, this difference reflects historical shifts in the discipline: from an era in which analyses were judged, if not according to the lights of functionalism proper, at least according to their fulfillment of functionoriented and more scientistic criteria, to one in which they are evaluated according to criteria of semiotic satisfaction. This is not to discount Evans-Pritchard's own keen sense of structural elegance. Empirical evidence as much as disciplinary trends determines that an ends-oriented account of witchcraft fits the Azande case but does not suit the Isoseño one. But recent "formal » explanations of witchcraft have hardly supplanted Evans-Pritchard's old-fashioned «functional » one, which still wins the popular vote in introductory anthropology classes. The problem is that meta-analyses do not contain within themselves a natural terminus of explanation. Anthropology's metacultural analysis, or CABI's, cannot trump culture. It can only engage it, perennially and to relentless criticism. *

* Manuscrit reçu en décembre 2006, accepté pour publication en juin 2007. 


\section{Notes}

1. Until recently, this was usually rendered as "Izoceno" " and Isoso as "Izozog ". In older literature, Isoseño are known variously as « tapii », " Chané of the Parapetí River », or included under the umbrella term "Chiriguano". The term and spelling used here reflect contemporary selfappellation.

2. I use pseudonyms erratically in this text. Some people in Isoso are "public figures »: CABI leaders, powerful payereta. It would be silly to use pseudonyms for these people, who are well known to anyone who has any familiarity with Isoso. For this reason, I only use pseudonyms for those people who would not otherwise be readily identifiable.

3. In reference to Isoso, Diego Villar $(2006$, p. 166) makes the point that « these same punishments meted out against witches evidence a sense of territorial unity " and contrasts the edicts of banishment used in Isoso to the situation in the related community of Guarani-speakers in which he works in Argentina, where collective ethnic identity is not so closely tied to a particular, delimited territory.

4. This is ceremony which I have never witnessed, but only been told about, when shamans come together and smoke hand-rolled cigars made of tobacco leaves wrapped in corn husks. They can " see far " when they do this and decide as a group who might be bewitching a person, holding back rain, or causing crop pestilence, and the like. I've never seen a good treatment of why the name of this ceremony has the form " $m b o »+$ "Spanish word [cigarro/singaru] "; this format is consistently how Spanish words are incorporated into the Guarani lexicon. At the very least, it suggests (as is the case in many other contexts in South America) that contemporary forms of shamanism are laden with « invented traditions " (leaving aside the pejorative dimensions of that term and literature).

5. This differs significantly from illness caused by the iyareta, the spirit-masters of the forest (which Don Jorge treats). Here, either wittingly (e.g., overhunting; wasting part of a catch) or unwittingly (e.g., staying out fishing too long and leaving one's children's souls vulnerable to snatching by the mbaebujo, river spirit), the victim has certainly transgressed norms of proper conduct vis-à-vis the iyareta, inviting illness.

6. "Little gringa ». The extra syllable is a Guaranization of the Spanish " gringa "; " $m i$ " is a diminutive.

7. I should make clear that CABI leaders did not have any direct expectations about what I might be able to do for the community. They know, particularly because of their experience with an American wildlife biologist who began as a lone researcher studying peccaries and ended up putting them in touch with the IVildlife Conservation Society and USAID, that cultivating good relationships with outsiders (especially Westerners) can sometimes have long-term benefits. However, they were by the same token sophisticated enough to recognize that a twenty-something graduate student present under nobody's particular auspices was not much of a resource in terms of goods or influence. CABI leaders and insiders usually displayed a benevolent disinterest in what I was up to, after I'd got their permission to be there. However, in the community I was sometimes challenged to explain my right to be present - and CABI associates would, on my behalf, invoke my potential long-term utility if they were present.

8. While $\mathrm{I}$ am constructing an argument here in terms of the specific constraints and opportunities facing the contemporary Capitanía, Hélène Clastres (1995, pp. 60-61; taken from Lozano 1754) summarizes text of a speech that almost exactly recapitulates this deferral; it is by a late-16th century Guaraní leader opening discussion at a " council of warriors ": " public affairs, involving the interest of all, cannot be guided by only the opinion of one person, even though he may be the wisest... Everyone should voice his opinion ").

9. New marital establishments in Isoso tend toward uxorilocality, though not in an explicit nor hard and fast way.

10. "In Guaraní... beautiful is not said for a natural arrangement » (Clastres 1995, p. 74).

11. Cadogan (1992/1959) relates that among the Guarani-speaking Mbyá of Paraguay the word " jeguakása" [decorated man] is used in ritual context to mean " man "; they call their "culture " " jeguakáva tenonde porängue $i$ » meaning, " the first [a connotation is " pre-eminent "] men to wear 
adornments »; they call their nearest Guarani-speaking neighbors " jeguakáva mir $\dot{t}$ " which could be translated « small, minor, or less-adorned men » (ibid., p. 14). The point is that adornment marks true personhood (Guaraní-speakers only are jeguakáva), and that such marking registers as scalable indices.

12. Isoso's pre-eminent public figure, the deceased father of the present Mburuvicha Guasu, was nicknamed " Kuaraia Guasu »: " Great Shade ".

13. Clastres (1995), Saignes (1990) and Combès (1992a; 1992b) document multiple references in the colonial literature to grand Guarani « assemblies » at which leaders, shamans, elders, and warriors (all men: though Isoseño oral histories, at least, tell of more than one woman leader who " knew how to speak »: Nordenskiöld 2002 [1912]; Combès 1999) would gather and speak in order to decide matters of importance to their communities (having often to do with outsiders: missions, military campaigns). These were also occasions for ritual generosity (characteristic also of the meetings I describe in the dissertation): " convites » (feasts) of chicha-drinking (Meliá and Temple 2004).

14. No equal and opposite tendency is manifested vis-à-vis the person toward modest dress. It will be interesting to see if this becomes a focus of creyente practice in years to come.

15. They worry about this with outsiders: researchers, NGO workers, etc. But they get particularly agitated about it when it comes to itinerant Andean traders: " colla " comerciantes who sell clothes or kitchen wares and come through on foot. People often commented to me, « there is money here in Isoso. Why else would the collas come? They know they can take advantage of us, they know a lot of money comes out of this place ". This is of course true as far as it goes, but their conviction that the traders - most of whom seemed to be leading a difficult, peripatetic, and hardly lucrative existence were all sharp dealers living of the fat of the Isoseño land seemed unwarranted.

16. People do, of course, hide things. One family I lived with had taken to storing all of their maize crop inside their house, rather than in the more traditional avati o, or raised outdoor granary: as the husband explained, " my wife has a lot of relatives, and if they see we have a lot of corn, they start to ask for it ". At a grander scale, CABI and various of its key personnel have repeatedly been involved in sticky financial mismanagement situations.

17. The parallels between Isoseño and Azande witcheraft are striking. In both the Azande and Isoseño cases witcheraft is substantive and inheres in the body; it travels by mysterious mechanisms (Azande, according to Evans-Pritchard (1937), like Isoseño, had little interest in considering its functional architectonics); it can be transmitted to younger kinspersons (although the transmission in the Isoseño case must involve intent, not simple heredity, and is not the only means of obtaining the witch-substance); witches are reputed to meet secretly and have organization, status, and hierarchy among themselves; witches may do their bewitching without particular malice; there is " professional jealousy " among "witch-doctors » (shamans). There are parallels in Isoseño and Azande social structures, as well: hereditary hierarchy (more developed among the Azande) and collective nostalgia for lost community spirit and control of witcheraft that was known under a legendary leader dead in recent memory: old King Gbudwe among the Azande; Kuarata Guasu, the father of Don Boni, among the Isoseno. And, as Evans-Pritchard memorably put it, 1930s Azande were " extremely annoyed " rather than frightened by witcheraft, as were 1990s Isoseño. There are, too, notable differences. No-one in Isoso persuades or importunes witches to cease and desist from their bewitching activities: preventive measures are not even considered. More centrally, the "function " of witch-discourse seems quite different (if I may be permitted to animate such a reviled analytic mode). Among the Azande, Evans-Pritchard tells us, witchcraft is invoked as a catch-all explanation for misfortune. From the famous collapsed granary to an infected stubbed toe, witchcraft answers the existential why behind the common-sensical one. Isoseno invoke witchcraft in relation to many things - illness, death, crop plagues, and drought - but not accidents. Furthermore, instead of eliminating the element of capriciousness from misfortune, witcheraft in Isoso seems only to heighten it. This is because witches themselves are in thrall to an uncontrollable impulse to do harm. Their actions are sometimes described as endless redemption of an unpayable «debt » to the source of their power (for more on this, see Lowrey 2006). If Azande witchcraft offers a terminus for explanation, Isoseno witchcraft points the way toward ever more unfathomable realms of conspiratorial malice. 


\section{REFERENCES CITED}

Albó Xavier

1990 Los guarani-chiriguano. 3. La comunidad hoy, CIPCA, coll. "Cuadernos de Investigación » 32, La Paz.

Bossert Federico and Diego VILLAR

2004 Imágenes de la sociedad y de la naturaleza entre los chané, Museo de Arte Precolombino/Fundación Nicolás García Uriburu, Buenos Aires.

Brown Michael

1993 "Facing the State, Facing the World: Amazonia's Native Leaders and the New Politics of Identity ", L'Homme, 33 (2-4), pp. 307-326.

\section{CADOGAN Leon}

1992 Ayvu Rapyta: Textos miticos de los mbayá-guarani del Guairá, Biblioteca Paraguaya de Antropología, Asunción [1959].

Ci.astres Hélène

1995 The land without evil: Tupi-Guarani prophetism, translated by Jacqueline Grenez Brovender, University of Illinois Press, Urbana [1975].

Comaroff Jean and John L. ComarofF

1993 Modernity and its malcontents: ritual and power in postcolonial Africa, University of Chicago Press, Chicago.

1999 "Occult economies and the violence of abstraction: notes from the South African postcolony ", American Ethmologist, 26, pp. 279-301.

2000 "Millennnial capitalism: First thoughts on a second coming », Public Culture, 12 (2), pp. 291-343.

Combès Isabelle

1992a La Tragédie cannibale chez les anciens Tupi-Guarani, Presses universitaires de France, Paris.

1992b Iyambae, une utopie chiriguanan, thèse de doctorat, EHESS, Paris.

1999 Arakae: historia de las comunidades Izoceñas, Capitanía del Alto y Bajo Isoso and Wildlife Conservation Society/Bolivia, Proyecto Kaa-Iya, Santa Cruz.

2005 Etno-Historias del Isoso: chané y chiriguanos en el Chaco boliviano (siglos XVI $a X X)$, Institut français d'études andines/Programa de Investigación Estratégica en Bolivia, La Paz.

Comis̀s Isabelle and Kathleen LowreY

2006 "Slaves without masters? Arawakan dynasties among the Chiriguano (Bolivian Chaco, XVI-XX centuries) ", Ethnohistory, 53 (4), pp. 689-714.

Combès Isabelle and Diego VILLAR

2004 "Aristocracias chané: « casas » en el chaco argentino y boliviano », Journal de la Société des Américanistes, 90 (2), pp. 63-102.

Conklin Beth and Laura Graham

1995 "This shifting middle ground: Amazonian indians and eco-politics », American Anthropologist, 97 (4), pp. 695-710. 
Evans-Pritchard Edward E.

1937 Witchcraft, oracles and magic among the Azande, Clarendon Press, Oxford.

FAVRET-SAADA Jeanne

1980 Deadly words: witchcraft in the Bocage, Cambridge University Press, Cambridge.

\section{Geschiere Peter}

1997 The modernity of witchcraft: politics and the occult in postcolonial Africa, University of Virginia Press, Charlottesville.

Hirsch Silvia

1991 Political organization among the Izoceño Indians of Bolivia, doctoral dissertation, Department of Anthropology, University of California, Los Angeles.

Hirsch Silvia and Angelica Alberico

1996 «El don de la palabra: un acercamiento al arte verbal de los guaraní de Bolivia y Argentina », Anthropos, 91 (1-3), pp. 125-137.

HiRSCH Silvia and Alexander ZARZYCKI

1994 «Ipayereta, Imbackuaareta, y evangelistas: cambios y continuidades en la sociedad izoceña ", in Jürgen Riester (ed.), Chiriguano, APCOB, Santa Cruz de la Sierra.

JACKSON Jean

1989 "Is there a way to talk about culture without making enemies? », Dialectical Anthropology, 14 (20), pp. 127-143.

Kulick Don

1992 «Anger, gender, language shift and the politics of revelation in a Papua New Guinean village ", Pragmatics, 2 (3), pp. 281-296.

LATOUR Bruno

1987 Science in action: how to follow scientists and engineers through society, Harvard University Press, Cambridge, MA.

\section{LOWREY Kathleen}

2003 Enchanted ecology: magic, science, and nature in the Bolivian Chaco, doctoral dissertation, Department of Anthropology, University of Chicago, Chicago.

2006 «Salamanca and the City: culture credits, nature credits, and the modern moral economy of indigenous Bolivia », Journal of the Royal Anthropological Institute, 12 (2), pp. 275-292.

Melí Bartomeu and Dominique Temple

2004 El don, la venganza y otras formas de economía guaraní, Centro de estudios paraguayos Antonio Guasch, Asunción.

MunN Nancy

1973 «Symbolism in a ritual context: aspects of symbolic action », in John J. Honigmann (ed.), Handbook of social and cultural anthropology, Rand McNally, Chicago, pp. 579-612.

1986 The fame of Gawa: a symbolic study of value transformation in a Massim (Papua New Guinea) society, Duke University Press, Durham, NC. 
NORDENSKIÖLD Erland

2002 La vida de los Indios: El Gran Chaco (Sudamérica), translated by Gudrun Birk and Angel E. Garcia, APCOB, La Paz [1912].

OAKDALE Suzanne

2004 «The culture-conscious Brazilian Indian: Representing and reworking Indianness in Kayabi political discourse ", American Ethnologist, 31 (1), pp. 60-75.

Peirce Charles Sanders

1955 "Logic as semiotic: the theory of signs ", in Justus Buchler (ed.), Philosophical writings of Peirce, Dover Publications, New York.

RIESTER Jürgen

1986 "Aspectos del chamanismo de los izoceño-guaraní », Suplemento Antropológico, 21 (1), pp. 263-283, Asunción.

SAIGNES Thierry

1990 Ava y karai: ensayos sobre la frontera chiriguamo, siglos XVI-XX, Hisbol, La Paz.

SeEger Anthony

1975 "The Meaning of Body Ornaments: A Suyá Example », Ethmology, 14 (3), pp. 211-224.

\section{SHAPIN Steven}

1979 "Homo Phrenologicus: Anthropological perspectives on an historical problem ", in Barry Barnes and Steven Shapin (eds), Natural order: historical studies of scientific culture, Sage Publications, Beverly Hills, pp. 41-71.

TAussig Michael

1980 The devil and commodity fetishism in South America, University of North Carolina Press, Chapel Hill.

TURNER Terence

1980 "The social skin ", in Jeremy Cherfas and Roger Lewin (eds), Not work alone: a cross-cultural view of activities superfuous to survival, Sage Publications, Beverly Hills, pp. 112-140.

1991 "Representing, resisting, rethinking: Historical transformations of Kayapó culture and anthropological consciousness », in George Stocking (ed.), Colonial situations, University of Wisconsin Press, Madison.

URBAN Gregory

2001 Metaculture: how culture moves through the world, University of Minnesota Press, Minneapolis.

Villak Diego

2006 La religion chané, doctoral dissertation, Department of Anthropology, University of Buenos Aires, Buenos Aires. 